\title{
Tokelau
}

\section{The last colony?}

\section{TONY ANGELO}

$S_{w}^{\mathrm{m}}$ ITUATED WELL NORTH OF NEW ZEALAND and Western Sāmoa and close to the equator, the small atolls of Tokelau, with their combined population of about 1600 people, may well be the last colony of New Zealand. Whether, when and in what way that colonial status of Tokelau will end, is a matter of considerable speculation.

The recently passed Tokelau Amendment Act 1996 - it received the royal assent on 10 June 1996, and came into force on 1 August 1996 - is but one piece in the colourful mosaic of Tokelau's constitutional development.

The colonialism that Tokelau has known has been the British version, and it has lasted so far for little over a century. This has been a varied history with the administrative capital of Tokelau being at various times in Tonga, Suva, Ocean Island, Apia and Wellington. A particular feature of
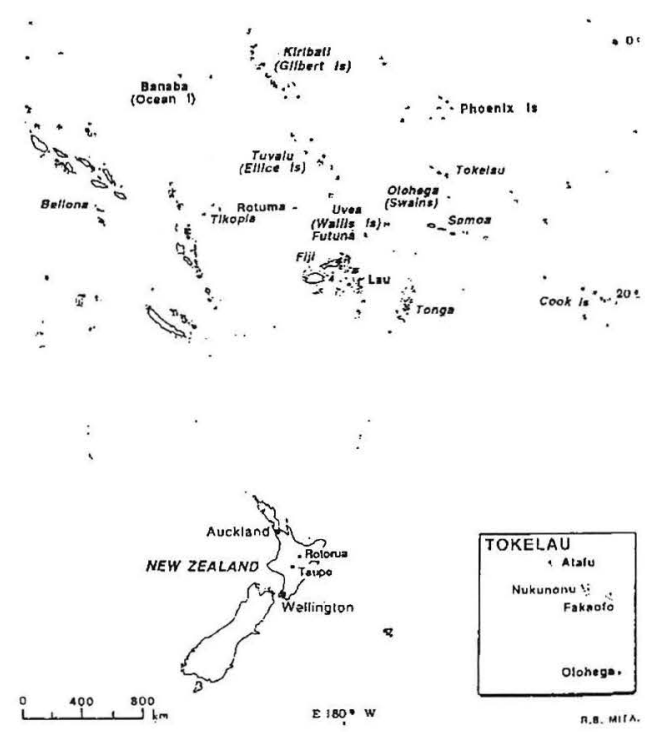

(Taupulega) is, and long has been, the governing body. The chairman (Faipule) of the council and a village head (Pulenuku) are elected by universal suffrage in the village every three years. The three councils send representatives to form the General Fono which is the Tokelau national authority; it originally met only once or twice a year and advised the New Zealand Government of Tokelau's wishes.

The General Fono frequently repeated advice, both to the New Zealand Government and to the UN Committee on Decolonisation, that Tokelau did not wish to change its status vis-à-vis New Zealand. However, in an unexpected change of position (stimulated no doubt by external factors such as the UN proposal to complete its decolonisation business by the year 2000), the Ulu of Tokelau (the Faipule of Nukunonu) stated to the UN Pacific Regional Seminar in June 1993 that 'it is Tokelau's wish to shoulder the new responsibilities'. This was followed in July 1994 by the presentation of a written statement of the Tokelau position to the UN Visiting Mission to Tokelau. The document was presented by the then Ulu of Tokelau (the Faipule of Fakaofo) after consultation with each village. The full title of this document in English is Tokelau's Voice: New Wind, New Waters, New Sail - The Emerging Nation of Tokelau.

In 1993 the process of scaling down the Tokelau Public Service, and of taking it home to Tokelau began in earnest. This was the beginning of Tokelau national government in the contemporary and decolonising sense. Within a short period of time, there were two significant delegations - those by the State Services Commissioner to Tokelau Public Service Commissioners, and the other by the Administrator of Tokelau to the Tokelau national forum, the General Fono, and (when the General Fono was not in session) to the Council of Faipule (an executive 
committee in the nature of a cabinet). At the New Zealand end, these developments had been foreshadowed by the appointment in 1992 of a full-time Administrator for Tokelau.

By 1994 an enquiry as to the degree of internal selfgovernment in Tokelau would have disclosed that there was a local judiciary and a local executive, and local budgetary and policy responsibility. There was, however, no local legislative power at the national level. Laws for Tokelau could only be made in Wellington. The fourth visit of a mission from the UN Special Committee on Decolonisation in 1994, the UN target for the eradication of colonialism by the year 2000, and the specific Tokelau needs for managing its fiscal affairs, put a focus on this absence of a legislative power.

The issue of a legislative power was one which had been discussed in Tokelau and with Tokelau over a number of years. In its early forms the request had been for a limited legislative power to deal with specified domestic matters with the intention that the power could be used on a trial basis in the first instance. The grant of such power never eventuated but, as a consequence of undertakings to Tokelau and to the UN Special Committee on Decolonisation, the 1996 Tokelau Amendment Act was passed and, among other things, it gave a domestic law-making power to the General Fono of Tokelau.

This Act is a significant step along the way to internal self-government for Tokelau in constitutional terms. It does not, however, represent full internal self-government. The legislative power is limited and subordinate to the powers of the New Zealand Parliament and those of the Governor-General in Council. Further, the main powers of the General Fono are executive powers, which are exercised by it as a delegate of the Administrator; the executive powers of the General Fono are held by delega- tion, not in its own right.

The key features of the new law-making power are that its exercise is subordinate to the powers of the New Zealand Parliament and to those of the Governor-General in Council. The powers may not be used to make laws which apply or have effect outside Tokelau, they may not be exercised to contradict any international obligation which affects Tokelau, and all rules made are subject to a power of disallowance by the Administrator within 30 days.

The 1996 Act is of interest not only because of the constitutional development of the legislative power but also because of the use of Tokelauan language in the preamble. This preamble covers two pages of text and sets the historical background to the grant of the legislative power and the purposes for which the power was granted. The Tokelauan language version precedes the English language version and reflects the initiative of the Select Committee. It was the Select Committee which proposed to Parliament, in its reporting back, that a preamble be added and that it include Tokelauan language text. This is a first, both for the New Zealand Parliament and for Tokelau. Additionally the translation of the preamble presented something of a linguistic challenge for Tokelau, because of the necessity to deal with alien concepts and to settle spellings in the context of a predominantly oral culture.

Will Tokelau meet the year 2000 deadline for decolonisation? In 1994 Tokelau committed itself to the process of development of internal self-government, but has expressly not committed itself to any timetable for achievement of full internal self-government or for the exercise of its right to self-determination. In order to advance the goals of internal self-government, Tokelau has since 1993 been very active. It has brought the Tokelau 
Public Service home from Apia in Western Sāmoa, it has significantly restructured the Public Service, it has developed its first national strategic plan, and set up a special committee on constitutional development.

The UNDP, a long term provider of aid to Tokelau, has been particularly supportive of the development of selfgovernment in Tokelau and the moves towards decolonisation. Of importance to the recent developments was UNDP support for a series of constitutional and government workshops in Tokelau in 1995. These workshops were significant. They extended across the whole of Tokelau and over a period of approximately five weeks. They were Tokelau organised, and Tokelau controlled, with one nonTokelauan participant who provided information and general support for the discussion of the constitutional

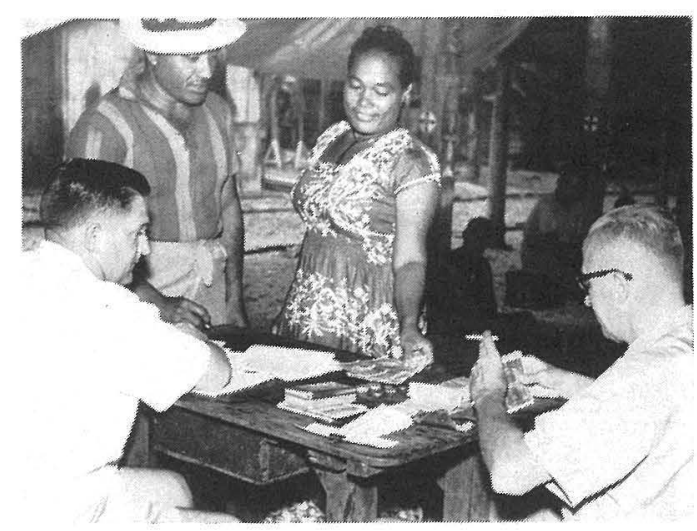

On boat day in 1956, each producer's copra was weighed and payment made by W G Potter, Paymaster of the Sämoan Treasury, Apia. The Tokelau Administration Officer, H L Webber, is seated on the left. Alexander Turnbull Library. their government. The workshops combined information, discussion groups and entertainment. They were in general very lively and pleasurable affairs. Their novelty, their informality, and the fact that they did not involve decision-making meant that people were free from the many inhibitions which would otherwise operate in Tokelau gatherings. There were several interesting features of this informality: The elders spoke of their relationship to the villages and to the villagers; General Fono delegates were asked questions about, and answered questions on their role in the General Fono and on the extent to which they reported their activities in the General Fono back to the villages; youth asked elders about the right of youth to participate in the government of Tokelau; women raised questions about gender stereotyping and gender discrimination issues. There was a three day constitutional workshop on each atoll involving, by invitation, the whole of the village. In the event, all workshops involved the elders, the women's group, the aumaga, the youth, and the churches. Attendance ranged on average between 60 and 90 persons.

The three day programme was divided into three clear parts. Day one related to the past and the historical development of government in Tokelau. Day two was concerned with identifying the features and purposes of the present governmental structures, and day three dealt with possible futures for Tokelau. The focus on

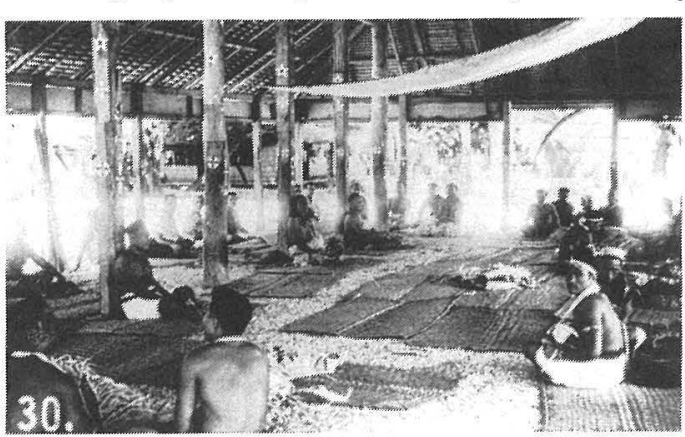

The meeting house in Nukunonu photographed before 1966 when it was destroyed by a hurricane. Elders or family heads are seated against the posts, while younger men sit around the perimeter. in village affairs; and senior secondary school children, as the future of Tokelau, participated on an equal basis.

Following these meetings on each island there was, at the end of the period, an inaugural two day meeting of the Special Committee on Constitutional Development. This is a group of over 30 persons, made up of three island subcommittees representative of those islands. The task of the Committee is to look to the development of a written constitution for Tokelau and to report back to the General Fono in late 1996 or early 1997 ; it had a special meeting in Western Sāmoa in November 1995, and another substantial internal self-government was established in the sessions of day two, and the discussions of day three culminated with a consideration of the self-determination options that Tokelau might consider when it had developed full internal self-government.

For many in Tokelau this series of workshops was the first time they had been involved in public discussion of meeting in Tokelau in April 1996. Each island sub-committee has produced a substantial report and some early indications of the potential constitutional development were set out in an interim report to the General Fono which was tabled in June 1996.

Where may all this be leading? Will Tokelau be another Western Sāmoa, a Cook Islands or a Niuē? It is 
unlikely that Tokelau will follow the models provided by these three states. Tokelau has in fact rejected the precise models provided by the Cook Islands and Niuē. As a matter of process, the current development is more in keeping with that followed by Western Sāmoa, but at the substantive level the product is unlikely to be like any of these three. The emphasis and discussion to date has been on the pre-eminence of Tokelau culture and on village government as the basis for all necessary national government. The goal will be to keep national government to the strict minimum and for national government action to be dependent on the support of the three villages of Tokelau.

Little indication has been given on the self-determination issues, but it does seem clear that Tokelau will expect current levels of New Zealand aid to continue in any post self-determination period, it will expect external help in respect of international relations, it would wish to maintain New Zealand citizenship rights, and would expect to have totally independent internal government. The roles of Head of Government and Head of State are likely to be combined in one person, with perhaps symbolic references to New Zealand and the Commonwealth. The government is likely to have a combined legislature and executive.
In terms of the "sacred trust" referred to in the Charter of the United Nations, New Zealand is doing what it believes is expected of it, and Tokelau in its turn is doing what it believes is expected of it. For Tokelau, this is all new. Nevertheless, it wants to find its own way and as a consequence is moving at its own speed. As at 1996, the development of national government in Tokelau was a fragile thing. The process raises the substantial question of how to be Tokelau (a unity) in a strange new world, where Tokelauans themselves have to deal with the day to day matters of national government. Self-determination puts a focus also on New Zealand activities, both in terms of the UN involvement and in terms of the New Zealand constituency provided by the 4500 Tokelauans who live in metropolitan New Zealand.

In the development towards self-determination in Tokelau, there is the possibility of conflict of interest for New Zealand. This is a potential dilemma and a challenge for both New Zealand and the United Nations. For Tokelau the challenge is to enter the 21st century in control of its own affairs. For New Zealand and the United Nations the challenge is to maintain into the 21st century the commitment and foresight shown in the idealism of 1945.

\section{A Tokelau chronology}

Entries in italics are relevant events which took place outside of Tokelau.

\section{Chronology of colonial accretion}

1765 Commodore John Byron on HMS Dolphin sights Atafu naming it Duke of York's Island. Atafu uninhabited at that time.

1791 Captain Edward Edwards of HMS Pandora sights Atafu during search for the Bounty mutineers, and sights inhabitants on beach at Nukunonu, naming it Duke of Clarence's Island.

1820 s Whalers operate in vicinity of Tokelau.

1835 First known European sighting of Fakaofo, when Captain Smith of the General Jackson names it De Wolf's Island.

1841 US Exploring Expedition spends several days among the atolls. Ethnologist Horatio Hale documents observations: estimates Fakaofo (named Bowditch Island) population at 500 - 600 and Atafu population at 120; islanders from Fakaofo on Olohega (Swains Island).

1845-1863 French Catholic and LMS missionaries to Tokelau: Atafu becomes Protestant; Nukunonu becomes Catholic; Fakaofo mixed Catholic and Protestant.

1863 Peruvian slave raiders take 140 people from Tokelau (virtually all the men removed). Dysentery outbreak further decimates population to approximately 200. By mid-1863 the Tui Tokelau statue (representing the traditional regime) has been destroyed.

1870s International rivalry between Britain, US and Germany over Sãmoa.

1874 Fiji ceded to Queen Victoria.
1877 UK establishes Western Pacific High Commission headquarters in Fiji.

1877 British High Commissioner for the Western Pacific given jurisdiction over British citizens in Tokelau.

1879 The Municipality of Apia established by the British High Commissioner for the Western Pacific.

1887 Wallis and Futuna become French protectorates.

1889 HMS Egeria visits atolls and declares Tokelau (Atafu, Fakaofo, Nukunonu, the Union Group) a British Protectorate. The Union Jack is raised. Population 600.

1892 British Protectorate declared over Ellice and Gilbert Islands.

1899 Sāmoa divided between Germany and the US.

1900 Niuẽ declared a British Protectorate.

1901 Niue annexed to New Zealand as part of the Cook Islands

1909 Tokelau made subject to the laws of the Gilbert and Ellice Islands Protectorate.

1914 Outbreak of WWI. A force of New Zealanders annex Western Sāmoa. New Zealand military occupation continues until 1920.

1916 Tokelau becomes part of Gilbert and Ellice Islands Colony.

1916 Gilbert and Ellice Islands Protectorate renamed Colony.

1925 Olohega (Swains Island) annexed by the US and placed under the administration of American Sāmoa. 


\section{Chronology of self determination}

1920 League of Nations turns administration of Western Sāmoa over to New Zealand and declares Western Sāmoa a Mandated Territory.

1926 Administration of Tokelau delegated to New Zealand and sub-delegated to the Administrator of Western Sāmoa. Population 1000.

1941 Atafu used as an American communication base during WWII.

1945 At end of WWII Sămoa becomes a UN Trust Territory administered by New Zealand.

1946 Americans use Bikini Atoll for atomic bomb tests

1947 New Zealand acquires unlimited legislative competence from UK, NZ Constitutional (Amendment) Act 1947.

1948 The Tokelau Islands Act enacted (effective from 1949). It provides for Tokelau to be part of New Zealand.

1960 UN Declaration on the Granting of Independence to Colonial Countries and Peoples.

1962 Western Sãmoa gains independence.

1964 First General Fono. Annual event by 1970s.

1966 Resettlement Scheme proposed for the people of Tokelau to migrate to New Zealand.

1965 Cook Islands self-determined.

1967 Tokelau Act amended:

1. to establish a Tokelau Public Service under the control of the State Services Commission; and

2. to provide for the control and administration of the freehold and customary land in the islands. Tokelau Public Service has its headquarters in Apia.

1970 Fiji becomes independent

1973 - 1980 More than 100 young people sent to school in New Zealand by the Scholarship Scheme.

1974 Administration of Tokelau transferred from the New Zealand Māori \& Island Affairs Department to Ministry of Foreign Affairs, under authority of New Zealand Secretary of Foreign Affairs. General Fono role modified to determine policies for the administration of Tokelau.

1974 Niue self-determined.

1976 First Visiting Mission from the UN Special Committee on Decolonisation. The Resettlement Scheme suspended, after assisting 528 people. Tokelau's exclusive economic zone defined.

1977 Office of Official Secretary established

1978 Tũvalu becomes independent.

1979 Kiribati becomes independent.

1981 Second Visiting mission from the UN Special Committee on Decolonisation.

1980 The Treaty of Tokehega signed and later ratified by the US and New Zealand in 1983.

1986 Third Visiting Mission from the UN Special Committee on Decolonisation. Tokelau reports that they are comfortable with the existing political status.

1986 South Pacific Nuclear Free Zone Treaty signed by Australia, Cook Islands, Fiji, Kiribati, New Zealand (thus including Tokelau), Niuē, Tūvalu, West Sāmoa, Papua New Guinea.

1987 First statement by Tokelau representative to the UN Committee on Decolonisation Cyclone.

Cyclone Tusi devastates Tokelau.

First Tokelauan Official Secretary.

At Port Moresby a Treaty of Fisheries is signed between the Governments of Certain Pacific Island States and the Government of the United States of America. (New Zealand signs on Tokelau's behalf).
1987 Military coup. Fiji proclaimed a Republic.

1988 Political unrest in New Caledonia. Matignon Accord, which provides for division of New Caledonia into three semi-autonomous provinces.

1989 Tokelau supports efforts by the South Pacific Forum to impose a regional ban on drift-net fishing.

Tokelau identity card introduced for travel to Western Sāmoa.

Cyclone Ofa causes unprecedented damage to Tokelau.

1992 New Zealand and Tokelau establish constitutional programme to provide Tokelau with formal powers to enable it to establish and operate its own national government.

1993 "From Lagoon to the Dark Ocean" Spokesperson from Tokelau addresses the UN Special Committee on the Situation with regard to the Implementation of the Declaration on the Granting of Independence to Colonial Countries and Peoples (at Port Moresby) stressing Tokelau's reliance on 'extra-budgetary sources'. The New Zealand Administrator of Tokelau says the confidence for self-government remains to be built.

Tokelau Public Service (TPS) restructured, and relocated to Atolls. A smaller Tokelau-Apia Liaison Office to replace the Office for Tokelau Affairs. Two TPS Commissioners appointed for five year terms, one New Zealand and one Tokelau-based. The position of Official Secretary disestablished and the Office of the Council of Faipule created.

1994 Faipule are Ministers at a National level (First National Government). Three important documents released:

1. The Letter of Understanding (relationship of Administrator to General Fono and Council of Faipule).

2. The National Strategic Plan.

3. The Voice of Tokelau (presented to the Fourth Visiting mission from the UN Special Committee on Decolonisation and self-determination) becomes part of Tokelau's agenda for the first time.

Statement by Tokelau's Special Representative to the UN Sub-Committee on the Situation with regards to the Implementation of the Declaration on the Granting of Independence to Colonial Countries and Peoples in New York. The status of Olohega (Swains) raised in this context.

1995 Tokelau's 'Year of the Constitution', constitutional workshops take place on each atoll. A Special Constitutional Committee established of $30+$ members.

1995 Cook Islands involved in New Zealand Winebox Inquiry.

1996 Second National government elected.

Administrator, Lindsay Watt, appointed by New Zealand for a further three-year term. Visit from Prime Minister of Tūvalu and the Memorandum of Understanding. Tokelau Amendment Act 1996 gives Tokelau limited legislative power.

1997 Visit of official party from American Sāmoa to discuss issues arising out of Tokohega Treaty [re Olohega/ Swains], in particular article VI.

Possible memorandum of understanding following the pattern of that with Tūvalu (February).

Inter-atoll telephones (7 March).

1998 New Caledonia will hold a referendum on its political future.

2000 Self-determination?

2000 UN deadline for eradication of colonialism. 